\title{
Corrigendum: The Autonomous Mind: The Right to Freedom of Thought in the Twenty-First Century
}

\author{
Simon McCarthy-Jones* \\ Department of Psychiatry, Trinity College Dublin, Dublin, Ireland
}

Keywords: human rights, privacy, psychology, law, machine learning, big data

\section{A Corrigendum on}

The Autonomous Mind: The Right to Freedom of Thought in the Twenty-First Century by McCarthy-Jones, S. (2019). Front. Artif. Intell. 2:19. doi: 10.3389/frai.2019.00019

An addition has been made to the Acknowledgments. The updated Acknowledgments statement appears below:

\section{ACKNOWLEDGMENTS}

\section{OPEN ACCESS}

Edited and reviewed by: Radboud Winkels,

University of Amsterdam, Netherlands

*Correspondence:

Simon McCarthy-Jones s.mccarthyjones@gmail.com

Specialty section: This article was submitted to

Technology and Law, a section of the journal Frontiers in Artificial Intelligence

Received: 25 February 2021 Accepted: 10 March 2021

Published: 15 April 2021

Citation:

McCarthy-Jones S (2021)

Corrigendum: The Autonomous Mind: The Right to Freedom of Thought in

the Twenty-First Century.

Front. Artif. Intell. 4:672279

doi: 10.3389/frai.2021.672279
"The author is grateful to the two reviewers of this paper, as well as Richard Mullender, Brendan Kelly, Patrick O'Callaghan, and Roseline McCarthy-Jones, for their insightful comments on this manuscript. The author would like to acknowledge Ms. Susie Alegre for introducing him to the right to freedom of thought in international law as applied to contemporary technological developments, including the work of Vermeulen (2006), Bublitz (2014), Bublitz and Merkel (2014) and Boire (2001). This framework was applied in a separate analysis in Alegre (2017).”

The author states that this does not change the scientific conclusions of the article in any way. The original article has been updated.

\section{REFERENCES}

Alegre, S. (2017). Rethinking freedom of thought for the $21^{\text {st }}$ century. Eur. Hum. Rights Law Rev. 3, 221-233. Available online at: https://susiealegre.com/wp-content/uploads/2020/04/Alegre\%20from\%202017_EHRLR_Issue_3_Print_final_0806 $\% 5$ B6745\%5D.pdf

Boire, R. G. (2001). On cognitive liberty. J. Cogn. Libert. 2, 7-22. doi: 10.1016/S1297-9562(01)90048-8

Bublitz, J. C. (2014). Freedom of thought in the age of neuroscience. Archiv Rechts-und Sozialphilosphie 100, 1-25.

Bublitz, J. C., and Merkel, R. (2014). Crimes against minds: on mental manipulations, harms and a human right to mental self-determination. Crim. Law Philosophy 8, 51-77. doi: 10.1007/s11572-012-9172-y

Vermeulen, B. (2006). "Freedom of thought, conscience and religion (article 9)," in Theory and Practice of the European Convention on Human Rights, 4th Edn, eds P. van Dijk, F. van Hoof, A. van Rijn, and L. Zwaak (Cambridge: Intersentia Press), 751-772.

Copyright (C) 2021 McCarthy-Jones. This is an open-access article distributed under the terms of the Creative Commons Attribution License (CC BY). The use, distribution or reproduction in other forums is permitted, provided the original author(s) and the copyright owner(s) are credited and that the original publication in this journal is cited, in accordance with accepted academic practice. No use, distribution or reproduction is permitted which does not comply with these terms. 